\title{
Papillary thyroid carcinoma in ovarian strumal carcinoid tumor: case report
}

\author{
Carcinoma papilifero de tireoide em tumor carcinoide strumal de ovário: relato de caso
}

Ana Paula Percicote ${ }^{1}$; Sérgio Bruno Bonatto Hatschbach²; Sérgio Ossamu Ioshii;

Tiago Jacometo Coelho de Castilho ${ }^{4}$; João Augusto Bahr'; Camila Gadens Zamboni ${ }^{6}$

\begin{abstract}
Strumal carcinoid tumor is an uncommon type of ovarian teratoma containing thyroid and carcinoid tissue. We report the case of a 49 year-old patient with menstrual irregularity. The ultrasonographic imaging revealed a mass in the left ovary. The histopathological assessment showed a papillary thyroid carcinoma in a strumal carcinoid tumor.
\end{abstract}

Key words: papillary carcinoma; strumal carcinoid.

\section{INTRODUCTION}

Carcinoid tumors are endocrine cell neoplasms commonly originated from the gastrointestinal tract and lungs. Primary ovarian carcinoid tumors are rare, corresponding to $0.52 \%$ of carcinoid tumors and $5 \%$ of ovarian tumors ${ }^{(8)}$. They are monodermal teratomas classified into different categories according to their histological aspect: insular, trabecular, strumal and mucinous ${ }^{(4,7)}$. The ovarian strumal carcinoid tumor is characterized by the combination of thyroid tissue and carcinoid tumor, though other teratoma components may be present ${ }^{(7)}$.

The thyroid tissue in the strumal carcinoid tumor shares morphological aspects as well as neoplastic and hyperplastic alterations generally described in the thyroid gland. The reports of association with papillary carcinoma, follicular carcinoma and adenomas are $\operatorname{rare}^{(0,10)}$. We report the case of a papillary thyroid carcinoma associated with strumal carcinoid tumor in patient with history of menstrual irregularity and ultrasound finding of a mass in the left ovary.

\section{CASE REPORT}

A 49 year-old female patient with history of four gestations and menstrual irregularity in investigation was referred due to ultrasound finding of a solid-cyst mass in the left ovary measuring $85 \times 86 \mathrm{~mm}$. Antigen carbohydrate 125 (CA125) $18.8 \mathrm{U} / \mathrm{ml}$ and carcinoembryonic antigen (CEA) $1.6 \mathrm{ng} / \mathrm{ml}$ screenings were normal. The patient did not present any signs and symptoms of hyperthyroidism or carcinoid syndrome.

Laparotomy revealed enlarged left ovary. The left adnexectomy was carried out. A preoperative frozen biopsy had been performed and a serous adenocarcinoma of the ovary had been diagnosed. Based on the yielded results, peritoneal liquid was collected and total hysterectomy was performed with resection of contralateral appendix and greater omentum. Furthermore, we collected samples of lymph nodes from iliac-obturator and para-aortic regions associated with multiple biopsies of the peritoneum, parietocolic gutters, infradiaphragmatic region and Douglas cul-de-sac. Peritoneal implants were not observed.

First submission on 23/09/12; last submission on 23/09/12; accepted for publication on 31/01/13; published on 20/04/13

1. Master's degree in Microbiology, Parasitology and Pathology by Universidade Federal do Paraná (UFPR); doctor.

2. Chief Gynecologist at the Gynecology Service of Erasto Gaertner Hospital.

3. Doctorate in Medicine by University of Mie; chief pathologist at the Pathology Service of Erasto Gaertner Hospital.

4. Resident in Surgical Oncology at Erasto Gaertner Hospital.

5. Resident in Pathology at Erasto Gaertner Hospital.

6. Medical academic at UFPR. 
Macroscopy evinced that the left ovary measured $9.6 \times 6 \times 5.5 \mathrm{~cm}$, with lobular, whitish, smooth and bright surface. The sections revealed solid-cystic lesion with solid, whitish and firm areas intermingled with unilocular cysts filled in with yellow gelatinous material. Microscopy showed neoplasia comprising thyroid tissue with follicles of varied sizes in most part of the lesion, intermingled with carcinoid tumor with trabecular and insular component, which exhibited a progressive transition and mixture of both elements. As to morphological findings, the diagnosis of carcinoid strumal was established. However, amidst the thyroid tissue surrounding the carcinoid tumor component, there was an extensive component of papillary thyroid carcinoma. It measured $2.5 \mathrm{~cm}$ at the longest axis, with classic papillary arrangement and typical nuclear characteristics such as nuclear overlapping, clearing, clefts and pseudo inclusion. There was also focal presence of calcifications (Figure 1).

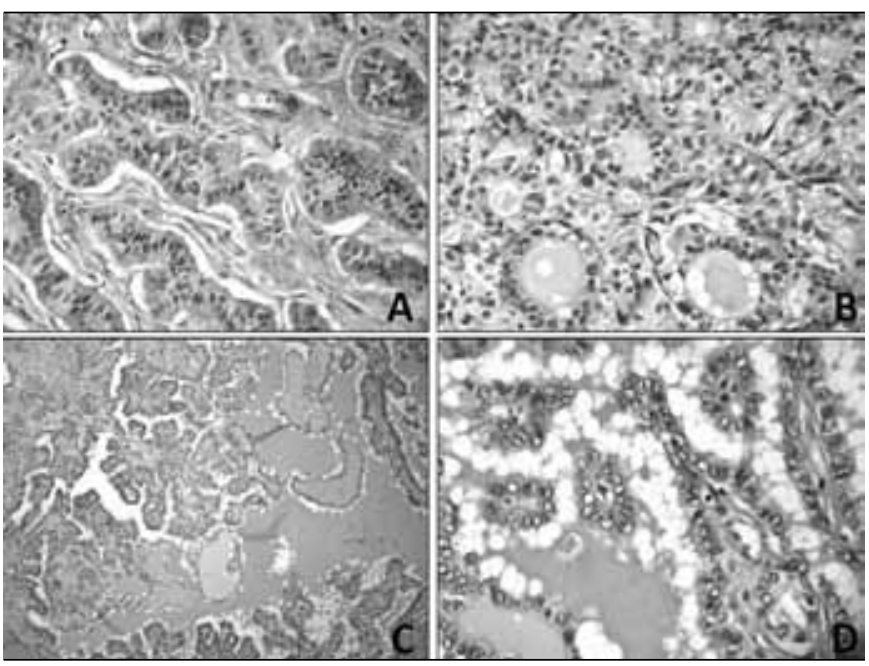

FIGURE 1 - Histological aspect of strumal carcinoid tumor and papillary thyroid carcinoma

(A) trabecular component of carcinoid (HE, 400×); (B) transition area between carcinoid component and thyroid follicles (HE, 400×); (C) classic variant of papillary thyroid carcinoma (HE, 100×); (D) typical nuclear characteristics of papillary thyroid carcinoma such as overlapping, clearance and nuclear clefts (HE, 400×)

HE: bematoxilin and eosin.

The immunohistochemical analysis was performed in order to confirm the coexistence of strumal carcinoid and papillary thyroid carcinoma. The reactions for chromogranin A and synaptophysin were positive for the carcinoid tumor component, highlighting the difference between carcinoid tumor and papillary thyroid carcinoma. Prostatic specific acid phosphatase (PSAP) screening yielded similar results. The immune reaction for thyroglobulin in the papillary thyroid carcinoma was positive (Figure 2).

After surgical procedure, the investigation was pursued with thyroid ultrasound and scintigraphy imaging, which demonstrated no lesions. The patient was referred to complementary therapy due to the lack of data in the literature to support neoadjuvant therapy. Currently, the patient is doing well, presenting no evidences of persistence or tumor relapse.

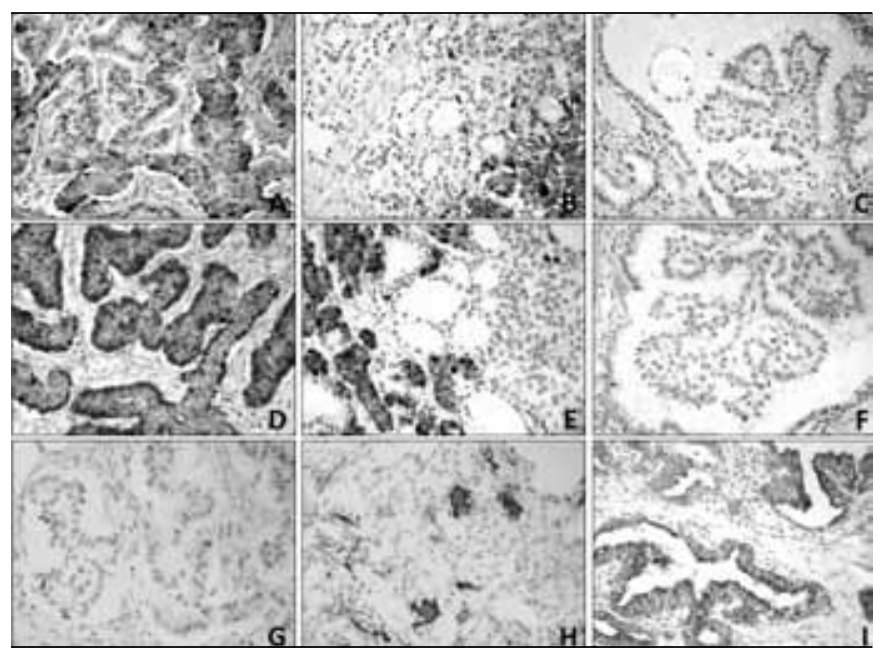

FIGURE 2 - Immunoexpression of histological components from strumal carcinoid tumor and papillary thyroid carcinoma

Chromogranin $A$ ( $A, B$ and $C), \operatorname{PSAP}(D, E$ and $F$ ) and thyroglobulin ( $G, H$ and I) immunoexpression in the trabecular carcinoid component from the transition area between the thyroid and carcinoid tissue and in papillary thyroid carcinoma. The reactions for chromogranin A and PSAP highlight the existence of bybrid cells in the transition areas between carcinoid and thyroid tissue (B and E) $(400 \times)$.

PSAP: Prostatic acid phosphatase.

\section{DISCUSSION}

Primary ovarian carcinoid tumors are uncommon and may be associated with teratoma elements, mucinous tumors and Sertoli-Leydig cell tumors. It is believed that these tumors originate from endocrine cells located in the gastrointestinal and respiratory epithelium of teratoma elements, neuroectodermal teratoma cells or endodermal cells present in the neoplasia ${ }^{(13,14)}$.

The strumal carcinoid tumor, previously denominated malignant struma ovarii, is not associated with specific clinical manifestations and metastases are rare ${ }^{(1,5,7)}$. The average age at diagnosis is 53 and most patients are asymptomatic. History of vaginal bleeding is reported in $16 \%$ of the cases ${ }^{(10)}$.

The origin of the thyroid tissue and carcinoid tumor components of these tumors is controversial. Some authors suggest the correlation of carcinoid tumor, $\mathrm{C}$ cells and thyroid medullar carcinoma. Based on ultrastructural evidences, other investigators assume the existence of hybrid cells with differentiation for thyroid and neuroendocrine cells similar to those found in carcinoid tumors derived from posterior intestine ${ }^{(6,10)}$. These findings are corroborated by morphological and immunohistochemical aspects such as positivity for PSAP, frequent among carcinoid tumors found in the posterior intestine ${ }^{(6)}$.

Macroscopy reveals the carcinoid tumor as a yellowish nodule associated with teratoma component ${ }^{(14)}$. The strumal carcinoid may be associated with dermoid cyst, mature teratoma, other neoplasias and thyroid tissue. The microscopic appearance of carcinoid associated with thyroid tissue varies according to the proportion 
and distribution of elements, as they may be contiguous or diffusely mixed. The carcinoid component is mostly trabecular, though it may be insular or present both aspects ${ }^{(10)}$.

The microscopic appearance of the trabecular component is similar to those carcinoids from posterior intestine. It comprises long and thin trabeculae constituted by two cells in thickness. The nuclei are displayed in parallel to each other and perpendicularly to the longest trabecular axis. On the other hand, the insular component, similarly to carcinoids from the middle intestine, comprises islands of solid cells separated by stroma. The cells have distinct edges and central nucleus with coarse chromatin ${ }^{(10)}$.

The components of carcinoid tumor and thyroid tissue are closely related to strumal carcinoid, mainly in areas close to interface, where there is a mixture of elements. In some other areas, it is possible to observe small thyroid follicles separated by carcinoid tumor and some follicles covered with neuroendocrine tumor cells ${ }^{(10)}$.

The neuroendocrine nature of the carcinoid tumor component may be confirmed through immunohistochemical positivity for chromogranin A and synaptophysin ${ }^{(2)}$. The immunoreaction for thyroglobulin and thyroid transcription factor (TTF-1) is variable. Markers such as somatostatin and PSAP are positive in the carcinoid components, whereas CEA, calcitonin and serotonin are negative ${ }^{(6)}$.

The thyroid tissue that constitutes the strumal carcinoid, similarly to the description of struma ovarii tissue, may present alterations similar to the thyroid gland, namely colloid goiter, follicular adenoma, follicular carcinoma and papillary carcinoma. The latter is the most common carcinoma ${ }^{(10)}$. For the diagnosis of both lesions, struma ovarii and struma carcinoid, histological criteria similar to those described for thryroid gland lesions are employed, although the presence of histological malignity represented by ovarian thyroid carcinomas does not reflect the biological behavior of these tumors, whose growth is restricted to the ovary and metastases are not normally present ${ }^{(3,11,12,14)}$.

There is no consensus on which criteria for the diagnosis of thyroid gland lesions could be applied in ovarian lesions, whether there would be specific ovarian elements or whether other histological criteria could predict the biological behavior of the neoplasia ${ }^{(11)}$.

In an attempt to find clinical and histological characteristics that correlate with extra ovarian spread in malignant struma ovarii, Robboy et al. ${ }^{(11)}$ analyzed 88 cases, of which 27 had extra ovarian spread, 12 were originated from tumors with malignant histology and 15 originated from adenomas or thyroid tissue without particularities. The strumal components with over $12 \mathrm{~cm}$ and adherences tend to have a higher frequency of biological malignity ${ }^{(11,12)}$.

The association between strumal carcinoid and papillary thyroid carcinoma is uncommon. Pelosi et $a l .{ }^{\left({ }^{9}\right)}$ report the case of a strumal carcinoid consisting of a mature cystic teratoma and thyroid tissue similar to colloid gaiter associated with a follicular cell focus of $1.2 \mathrm{~mm}$ with typical morphological alterations of the follicular variant of papillary thyroid microcarcinomas.

\section{CONCLUSION}

In conclusion, strumal carcinoid is a teratoma consisting of varied proportions of the thyroid tissue and carcinoid tumor with histological, and immunohistochemical characteristics similar to those found in carcinoid tumors of the posterior intestine. Despite the rare association of thyroid carcinomas and strumal carcinoid, this possibility should be acknowledged.

\section{RESUMO}

Carcinoide strumal é uma forma incomum de teratoma ovariano que contém tecido tireoidiano e carcinoide. Relatamos o caso de uma paciente de 49 anos de idade, cuja investigação por irregularidade menstrual revelou massa em ovário esquerdo à ultrassonografia. A avaliação bistopatológica da massa apresentou carcinoma papilífero de tecido tireoideano em carcinoide strumal.

Unitermos: carcinoma papilífero; carcinoide strumal.

\section{REFERENCES}

1. ARMES, J. E.; ÖSTÖR, A. G. A case of malignant strumal carcinoid. Gynecol Oncol, v. 51, n. 3, p. 419-23, 1993.

2. DAVIS, K. P. D. et al. Primary ovarian carcinoid tumors. Gynecol Oncol, v. 61, n. 2, p. 259-65, 1996.

3. DEVANEY, K. et al. Proliferative and histologically malignant struma ovarii: a clinicopathologic study of 54 cases. Int J Gynecol Pathol, v. 12, n. 4, p. 333-43, 1993.
4. DÍAZ-MONTES, T. P. et al. Primary insular carcinoid of the ovary. Gynecol Oncol, v. 101, n. 1, p. 175-8, 2006.

5. KHADILKAR, U. N. et al. Ovarian strumal carcinoid - repot of a case that metastasized. Indian J Pathol Microbiol, v. 43, n. 4, p. 459-61, 2000.

6. KIMURA, N.; SASANO, N.; NAMIKI, T. Evidence of hybrid cell of thyroid follicular cell and carcinoid cell in strumal carcinoid. Int J Gynecol Pathol, v. 5, n. 3, p. 269-77, 1986.

7. KURABAYASHI, T. et al. Primary strumal carcinoid tumor of the ovary with multiple bone and breast metastases. J Obstet Gynaecol Res, v. 36, n. 3 , p. $567-71,2010$. 
8. MODLIN, I. M.; SANDOR, A. An analysis of 8305 cases of carcinoid tumors. Cancer, v. 79, n. 4, p. 813-29, 1997.

9. PELOSI, G.; SONZOGNI,A.; ROSAI,J. Thyroid-type papillarymicrocarcinoma in ovarian strumal carcinoid. Int J Surg Pathol, v. 16, n. 4, p. 435-7, 2008.

10. ROBBOY, S. J.; SCULLY, R. E. Strumal carcinoid of the ovary: an analysis of 50 cases of a distinctive tumor composed of thyroid tissue and carcinoid. Cancer, v. 46, n. 9, p. 2019-34, 1980.

11. ROBBOY, S. J. et al. Malignant struma ovarii: an analysis of 88 cases, including 27 with extraovarian spread. Int J Gynecol Pathol, v. 28, n. 5, p. 405-22, 2009 .
12. ROTH, L. M. et al. Risk factors in thyroid-type carcinoma arising in ovarian struma: a report of 15 cases with comparison to ordinary struma ovarii. Histopathology, v. 57, n. 1, p. 147-67, 2010.

13. RUSSELL, P.; ROBBOY, S. J.; PRAT, J. Ovarian germ cell tumors. In: ROBBOY, S. J. et al. Robboy's Pathology of the female reproductive tract. London: Churchill Livingstone, 2009, p. 729-75.

14. TALERMAN, A.; VANG, R. Germ cell tumors of the ovary. In: KURMAN, R. J.; ELLENSON, L. H.; RONNETT, B. M. Blaustein's pathology of the female genital tract. New York, NY: Springer, 2011, p. 847-907. 